\title{
Література:
}

1. Бендерська О. В. Удосконалення технології томатних соусів із додаванням пасти із насіння томатів : автореф. дис. ... канд. техн. наук : спец. 05.18.13 «Технологія консервованих i охолоджених харчових продуктів». НУХТ. Київ, 2019. 23 с.

2. Benderska O., Bessarab A., Shutyuk V. Research of fatty acidcomposition of tomato seeds. Technology audit and production reserves. Vol. 4, No 3(42). 2018.

3. Marcus, J.B. Culinary nutrition: the science and practice of halthy cooking. New York: Academic Press.1. 2013.

DOI https://doi.org/10.30525/978-9934-26-109-1-18

\section{INFLUENCE OF MORPHOLOGICAL STRUCTURE OF PORK ON THERMOPHYSICAL CHARACTERISTICS IN THE PROCESS OF FREEZING-DEFROST}

\author{
Dromenko O. B. \\ Candidate of Technical Sciences, Associate Professor, \\ Associate Professor of the Department of Meat Technology \\ Kharkiv State University of Food Technology and Trade \\ Yancheva M. O. \\ Doctor of Technical Sciences, Professor, \\ Head of the Department of Meat Technology \\ Kharkiv State University of Food Technology and Trade \\ Bogaditsa O. O. \\ Master's Degree Student of the Department of Meat Technology \\ Kharkiv State University of Food Technology and Trade \\ Kharkiv, Ukraine
}

Frozen meat has become an important product of international trade [1], and modern consumers want the quality of frozen products to match the level of chilled [2;3]. The search for new, modern and economical methods of preserving the quality of frozen meat products is important [4-6].

It is known that the loss of meat during refrigeration is affected by the content of adipose tissue [7-9]. 


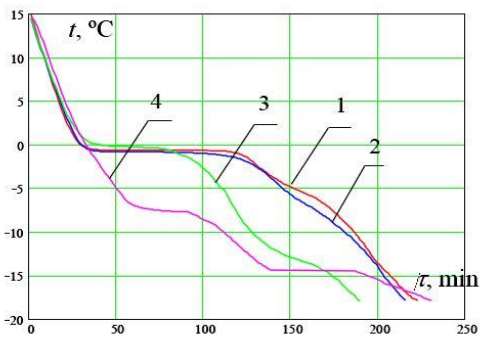

freezing

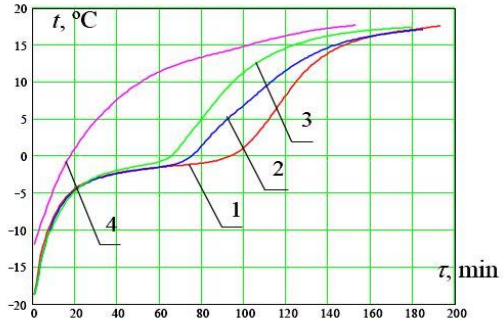

defrosting

Fig. 1. Thermogram of the process of freezing-defrosting meat systems:

1 -lean pork; 2 - semi-fat pork; 3 -fatty pork; 4-lard

Table 1

Parameters of the temperature dependence of effective specific thermal capacity of comminuted meat systems pork of different varieties and lard

\begin{tabular}{|l|c|c|c|c|}
\hline \multirow{2}{*}{ Parameters } & \multicolumn{5}{|c|}{ Pork } \\
\cline { 2 - 5 } & lean & semi-fat & fatty & lard \\
\hline \multicolumn{5}{|c|}{ At freezing } \\
\hline$T_{\mathrm{cr}},{ }^{\circ} \mathrm{C}$ & $-0,7$ & -1 & $-0,4$ & - \\
\hline$\Delta \mathrm{T}_{\mathrm{cr}},{ }^{\circ} \mathrm{C}$ & 1,5 & 1,9 & 2,6 & - \\
\hline$\Delta H_{c r}, \mathrm{~J} / \mathrm{K}$ & 88 & 74 & 55 & - \\
\hline$\Delta H, \mathrm{~J} / \mathrm{K}$ & 207 & 189 & 179 & 258 \\
\hline$\Delta \omega$ & 0,26 & 0,22 & 0,17 & - \\
\hline \multicolumn{5}{|c|}{ At defrosting } \\
\hline$T_{\mathrm{cr}},{ }^{\circ} \mathrm{C}$ & $-1,7$ & $-2,1$ & $-1,9$ & - \\
\hline$\Delta \mathrm{T}_{\mathrm{cr}},{ }^{\circ} \mathrm{C}$ & 8,1 & 8,8 & 7,2 & - \\
\hline$\Delta H_{c r}, \mathrm{~J} / \mathrm{K}$ & 95 & 59 & 51 & - \\
\hline$\Delta H, \mathrm{~J} / \mathrm{K}$ & 180 & 164 & 154 & 103 \\
\hline$\Delta \omega$ & 0,28 & 0,18 & 0,15 & - \\
\hline
\end{tabular}

The aim of the study was to determine the influence of the morphological structure of pork on thermophysical parameters in the process of freezing-thawing.

To obtain meat systems used category II pork according to DSTU 7158: 2010 "Meat. Pork in carcasses and carcasses. Specifications": lean pork (muscle tissue with a mass fraction of adipose tissue 10\% in the skin or without the skin); semi-fat trimmed pork (muscle tissue with a mass 
fraction of adipose and connective tissue $30-50 \%$ in the skin or without the skin); Pork trimmed fat (muscle tissue with a mass fraction of adipose and connective tissue not more than $80 \%$ in the skin or without the skin); lard sausage lateral, backbone according to the current regulatory documents.The technique for obtaining minced meat systems and the method of research into thermal-physical characteristics of minced meat systems are described in paper [10].

Examples of the thermograms curves of samples freezing-defrosting were of the shape shown in Fig. 1.

For revealing and comparing thermodynamic changes during refrigeration, used the method of to determine the effective specific thermal capacity by thermograms of freezing-defrosting and a set of information parameters (Table 1) associated with it [11].

The study of thermophysical characteristics of meat systems based on minced pork with different chemical composition in the process of freezingthawing. Information parameters of temperature dependence of effective specific heat capacity are received: $T_{\text {cr }}-$ cryoscopic temperature, ${ }^{\circ} \mathrm{C} ; \Delta \mathrm{T}_{\text {cr }}-$ cryoscopic interval of temperatures, ${ }^{\circ} \mathrm{C} ; \Delta H_{c r}$ - specific heat capacity of phase transition in a cryoscopic interval of temperatures, $\mathrm{J} / \mathrm{K} ; \Delta H$ is the change in enthalpy in the temperature range $(\Delta T)$ of the measured sample, $\Delta T, \mathrm{~J} / \mathrm{K}$. The proportion of moisture $(\Delta \omega)$ - that share of moisture, which changes its aggregate state in a cryoscopic interval of temperatures). It is shown that the morphological structure of meat (the ratio of muscle, connective and adipose tissue) and its chemical composition significantly affect the thermophysical parameters of meat systems in the process of freezing and thawing. It is revealed that under the conditions of freezingthawing cycle with increasing mass fraction of fat in the meat system there is an increase in cryoscopic temperature, decrease in cryoscopic temperature range, increase in moisture content, which changes its physical state in cryoscopic temperature range, increase in specific heat of phase transition. cryoscopic temperature range. The nature of the change in the cryoscopic temperature range allows us to determine that the presence of fat significantly affects the freezing-thawing process.

\section{References:}

1. Leygonie C., Britz T.J., Hoffman L.C. Impact of freezing and thawing on the quality of meat : Review. Meat Science. 2012. Vol. 91(2). P. 93-98. URL: https://doi.org/10.1016/j.meatsci.2012.01.013.

2. Alonso V., Muela E., Tenas J., Calanche J.B., Roncalés P., Beltrán J.A. Changes in physicochemical properties and fatty acid composition of 
pork following longterm frozen storage. European Food Research and Technology. 2016. Vol. 242(12). P. 2119-2127. URL: https://doi.org/ 10.1007/s00217-016-2708-y.

3. Leroy F., Degreef F. Convenient meat and meat products. Societal and technological issues. Appetite. 2015. Vol. 94. P. 40-46.

4. Jackson P., et al. A Short History of Convenience Food. Reframing Convenience Food. 2018. P. 15-38.

5. Shajil S., Mary A., Juneius C.E.R. Recent Food Preservation Techniques Employed in the Food Industry. Microbial Biotechnology. 2018. Springer. P. 3-21.

6. Zhan X., et al. Improving the quality and safety of frozen muscle foods by emerging freezing technologies: A review. Critical reviews in food science and nutrition. 2017. P. 1-14.

7. Farouk M.M., Wieliczko K.J. Effect of diet and fat content on the functional properties of thawed beef. Meat Science. 2003. Vol. 64(4). P. 451-458. URL: https://doi.org/10.1016/S0309-1740(02)0021314-0.

8. Wang Y., Liang H., Xu R., Lu B., Song X., Liu B. Effect of temperature fluctuations on the meat quality and muscle microstructure of frozen beef. International Journal of Refrigeration. 2020. Vol. 116. P. 1-8. URL: https://doi.org/10.1016/j.ijrefrig.2019.12.025.

9. Öztürk-Kerimoğlu B., et al. Cold-set or hot-set emulsion gels consisted of a healthy oil blend to replace beef fat in heat-treated fermented sausages. Meat Science. 2021. Vol. 176. P. 108461. URL: https://doi.org/ 10.1016/j.meatsci.2021.108461.

10. Yancheva M., Dromenko O., Potapov V., Grinchenko O., Zhelieva T. Study of influence of freezing-defrosting on thermophysical properties of meat systems. EUREKA: Life Sciences. 2018. Issue 1. P. 32-38. DOI: 10.21303/2504-5695.2018.00537.

11. Yancheva M., Dromenko O., Potapov V., Grinchenko O., Zhelieva T. Development of a physicalmathematical model for the process of crystallization of meat systems. Восточно-Европейский журнал передовых технологий. 2018. Vol. 1(11). Р. 50-55. 